\title{
Semsey Gábor
}

Semmelweis Egyetem EKK - Mentálhigiéné Intézet

\section{Szexuális nevelés az iskolában}

Az iskolai szexuális nevelés alapvetéseit foglaljuk össze jelen tanulmányunkban. Foglalkozunk a szexuális nevelés fogalmi megközelitéseivel, definíciós kísérleteivel a kortárs szexuálpedagógiában, felvillantjuk a szexuális nevelés és más nevelési területek kapcsolódásait, majd kifejtjük, a szakirodalom milyen célkitúzéseket és módszertani alapelveket tart szükségesnek az iskolai szexuális nevelés terén. Tisztázzuk ennek a kapcsán a pszichoszexuális érettség fogalmát, és körüljárjuk a szexualitás kapcsán megjelenó erkölcsi kérdések problematikáját is.

\section{Bevezetés}

A szexuális nevelés egyike a legfontosabb nevelési területeknek, hiszen az emberi szexualitás (továbbá azok a kapcsolatok, amelyekben a szexualitást megéljük) az életminőséget számos területen befolyásolja. Ahogy a szexualitás 20. századi történetéről monográfiát író Angus McLaren (2002. 21.) idézi W. C. Field frappáns mondatát: „A szex nem a legfontosabb dolog a világon, de nincs semmi, ami hozzá fogható”.

Ha a nevelés felől nézzük: Fábián Róbert és Simich Rita, az Országos Egészségfejlesztési Intézet munkatársai szerint ,a legfontosabb és legösszetettebb nevelési feladatra vállalkoznak azok, akik ebben vállalnak részt” (Fábián és Simich, 2006. 21.). Ha túlzó is ez a megfogalmazás, tanulmányunkból remélhetőleg kiderül, hogy csakugyan fontos és összetett nevelési feladatról van szó.

Hogy a szexuális nevelés helyzete Magyarországon nem megnyugtató, azt a szakemberek vélekedése is megerősíti. Lux Elvira, a hazai szexuálpszichológia egyik meghatározó alakja szerint „korunk nemi betegsége a szexuális kulturálatlanság” (2000. 12.). A szexuális kultúra (és a párkapcsolati kultúra) növekedéséért legtöbbet valószínűleg éppen a szexuális nevelés tehet. Ez természetesen nemcsak az iskolában kell, hogy történjen (kiemelkedően fontos például a család szerepe), de az iskolának biztosan jelentős szerepet kell ebben vállalnia.

Magyarországon azonban, fontossága ellenére, a szexuális nevelés a pedagógia számos más területéhez képest elhanyagolt. Vannak persze üdvözlendő kezdeményezések Magyarországon is. Azonban a területtel foglalkozó magyar szakemberek közül sokan egyáltalán nem elégedettek az eddigi eredményekkel.

Berend Mihály és Péterfia Éva (1998. 9.) például ezt írták tanári kézikönyvükben: „Hogyan készít fel jelenleg az iskola a családi életre? Ha nem akarjuk a valóságot szépíteni [...], csak azt írhatjuk, sehogyan sem". De még 2006-ban is így fogalmazott Buda Béla (2006. 9.) egy szexuálpedagógiai tankönyv előszavában: „,a szexuálpedagógia talán a nevelésügy legfejletlenebb ágazata, mind elméleti, mind gyakorlati szempontból”.

Az Országos Egészségfejlesztési Intézet munkatársainak néhány évvel ezelötti országos, reprezentatív kutatása azt bizonyította, hogy a diákok szexualitásra vonatkozó 
ismeretei minden szempontból elégtelenek, így ők is azt a következtetést vonták le, hogy az iskolai szexuális nevelés komoly fejlesztésre szorul (Simich és mtsai, 2010).

Sőt úgy tünik, nem elégedettek a fiatalok sem, akiket a szexuális nevelés céloz. Egy 2008-ban zárult felmérés szerint (amelyben 1500 föt kérdeztek meg) a fiatalok 97\%-a elégedetlen a jelenleg müködő szexuális neveléssel, mivel annak keretében nem esik elég szó az érzelmekröl, a párkapcsolatokról és a nemi szerepekről (Kolonits és Tárkányi, 2010).

Pedig - ahogy Szilágyi Vilmos (2006. 205.) fogalmaz - ,,az eddig elhanyagolt szexuálpedagógia elméleti és gyakorlati müvelése igen kedvező lehetőségeket rejt magában egész köznevelésünk továbbfejlesztése szempontjából”.

Hogy a szexuális nevelés magyarországi helyzete nem megnyugtató, azt bizonyos népegészségügyi adatok is alátámasztják. Érdemes néhány adatot idézni a Nemzeti Egészségfejlesztési Intézet által kiadott Egészségjelentés 2015 címü kiadványból (mely számos más szervezettel való együttmüködésben készült):

- „Az elmúlt évtizedben a szexuális úton terjedő fertőzések (például syphilis, urogenitális chlamydiasis, gonorrhoea) száma egyértelmüen növekvő tendenciát mutatott. 2014-ben összesen 271 újonnan diagnosztizált HIV-fertőzést regisztráltak, 13\%-kal többet, mint az elmúlt évben. [...] Az elmúlt évben 51 AIDS megbetegedést diagnosztizáltak, és 15 beteg halt meg a tünetegyüttes következtében" (Egészségjelentés, 2015. 40. o.).

- A szexuális bántalmazás és erőszak az országnak 2010-ben az abból fakadó egészségveszteséghez kapcsolódóan 50 milliárd forint becsült gazdasági veszteséget okozott, a 15 év feletti korosztályt figyelembe véve (uo. 50.). Hozzáteszik ehhez a szerzők: „A kockázati tényező sajátosságaiból adódóan azonban vélhetően az adatok alulbecsültek, és valószínüsíthető, hogy a szexuális bántalmazás következtében kialakuló lelki sérülések sem jelennek meg teljes mértékben ebben a kockázati csoportban" (uo. 53.).

- „A szexuális bántalmazás és erőszak miatt, mely föként mentális zavarok képében jelentkezik, 126 egészséges életévet vesztettek el az 5-14 éves gyermekek 2010ben. A téma érzékenységét, az elérhető adatok megbízhatóságának sajátosságait figyelembe véve arra lehet következtetni, hogy ez egy jelentösen alulbecsült érték" (uo. 55.).

- „A magyar abortuszok száma jelentősen meghaladja az EU-ban tapasztalható értékeket. 2012-ben például minden 1000 magyar élveszületésre 400 abortusz esett, míg ez a szám az EU15-ben 223, az EU13-ban 203 volt" (uo. 86.).

Ehhez tegyünk hozzá néhány adatot a Központi Statisztikai Hivatal 2016-ban megjelent Magyarország, 2015 címü kiadványából:

- „A párkapcsolatban élő 15 éves és annál idősebb népesség aránya az 1990. évi 59\%ról 2011-re 51\%-ra csökkent” (KSH, 2016. 16.). (Ebbe a házasságban és az élettársi kapcsolatban élöket egyaránt beleszámolták.)

- A válások száma 1990 és 2010 között nagyjából stagnált. „Az ezután kezdődő csökkenő irányzat 2015-ben megállt, és a válások száma ismételten emelkedett: 20,6 ezer bontóperi végzést hoztak, az előző évinél 5,2\%-kal többet” (uo. 17.).

- „A házasságok mérlege 38 éve folyamatosan negatív, vagyis több házasság szünik meg válás vagy özvegyülés miatt, mint amennyit kötnek" (uo. 17.).

Ezek az adatok is azt mutatják, hogy bőven van tennivalónk a szexuális nevelés, a párkapcsolatokra és a házasságra való felkészítés terén. 


\section{A szexuális nevelés fogalma a kortárs szexuálpedagógiában}

Hogyan definiálhatnánk magát a szexuális nevelést? (A továbbiakban hol a nemi nevelés, hol a szexuális nevelés kifejezést használjuk, a szóismétlés elkerülése végett.)

Ebben a fejezetben nem kívánjuk történeti oldalról vizsgálni ezt a kérdést. Inkább arra vagyunk kíváncsiak, hogy a kortárs szexuálpedagógiai kutatás milyen fogalmi keretben gondolkodik a szexuális nevelésről.

A szexuális nevelés fogalmát a szexuálpedagógiai kutatók is többféleképp próbálják meghatározni. Abban azonban alapvetően megegyeznek, hogy a szexuális nevelés fogalmát igen átfogóan definiálják.

Nézzünk meg néhány definíciós kísérletet különböző országok kutatóitól:

1. Az UNESCO 2009-es, igen fontos kiadványában, amely nemzetközi útmutatót ad a szexuális neveléshez, a következőképpen definiálják a szexuális nevelést (International Technical Guidance, 2009): ,életkornak megfelelö, kulturális szempontból releváns megközelítése a szexre és a kapcsolatokra vonatkozó oktatásnak, amelyet tudományosan pontos, realisztikus, ítélkezéstől mentes információk alapoznak meg. A szexuális nevelés alkalmat kínál a saját értékek és attitüdök megvizsgálására, illetve döntéshozatali, kommunikációs és kockázatcsökkentő képességek kialakítására a szexualitás számos aspektusával kapcsolatban” (saját fordítás). ${ }^{1}$

Ez a definíció tulajdonképpen már számos kritériumot el is vár a szexuális neveléstől: pl. a kulturális adottságok figyelembevételét, a tudományos megalapozottságot stb. Vagyis eszerint csak bizonyos kritériumok teljesülése esetén nevezhető szexuális nevelésnek a szexualitásra és a párkapcsolatokra vonatkozó oktatás.

2. A WHO által 2010-ben kiadott dokumentumban, amely az európai szexuális neveléshez fogalmaz meg irányelveket (WHO - BZgA, 2010), így fogalmaznak a szerzők: „A szexuális nevelés a nemiség kognitív, emocionális, szociális, interaktív és testi vonatkozásainak megtanulását jelenti." Ez a definíció, mint látjuk, szintén hangsúlyozza, hogy a nemi nevelésnek komplexnek kell lennie, számos aspektus vizsgálatát tartja szükségesnek.

3. Egy mexikói kutatás kapcsán a szerzők arra a következtetésre jutottak, hogy a szexuális nevelés tágan értelmezett definíciója lenne kívánatos, amely előtérbe helyezi a családi kommunikációt, az értékek tisztázását, a nők felkészítését az anyaságon kívüli szerepekre is (Weiss, Atkin, Gribble és Andrade-Palos, 1991). A szerzők tehát itt először (a kutatásuk alapján) meghatározták, milyen tartalmakra lenne szükség az iskolai nevelésben a párkapcsolat, szexualitás kérdéskörben, és a szexuális nevelés fogalmát ezek fényében tartják definiálandónak. (Azonban a definíciót, mint olyat, ők nem alkotják meg.)

4. A jimmai egyetem (Etiópia) egészségneveléssel foglalkozó munkacsoportja olyan definícióját alkotta meg a szexuális nevelésnek, amely egészen részletes leltárt ad a nemi nevelés kívánatosnak tartott tartalmáról. Eszerint a szexuális nevelés az alábbi tartalmakról szóló oktatás-nevelés: „az ember szexuális anatómiája, szexuális reprodukció, szexuális érintkezés, reproduktív egészség, érzelmi viszonyok, reproduktív jogok és felelösségek, absztinencia, fogamzásgátlás, családtervezés, testkép, nemi orientáció, nemi gyönyör, értékek, döntéshozatal, kommunikáció,

1 Az eredetiben: „Sexuality Education is defined as an age-appropriate, culturally relevant approach to teaching about sex and relationships by providing scientifically accurate, realistic, non-judgemental information. Sexuality education provides opportunities to explore one's own values and attitudes and to build decision-making, communication and risk reduction skills about many aspects of sexuality" (International Technical Guidance, 2009. 2.). 
randevúzás, kapcsolatok, nemi úton terjedő betegségek és azok megelőzése, valamint a születésszabályozás módszerei” (Netsanet, Tsion, Fessahaye és Fentie, 2012. 99., saját fordítás). ${ }^{2}$

Az ilyen típusú, „lajstromozó” definíciók hátránya az, hogy bármilyen körültekintően alkotják is meg öket, kimaradhatnak olyan témák, amelyeket egyébként indokolt lenne a nemi nevelés részeként megjeleníteni.

5. Holger Frederick Kilander amerikai szexuálpedagógus definíciója elkerüli ezt a csapdát: „A szexuális nevelés mai megfogalmazásban magában foglalja mindazokat a nevelési eljárásokat, amelyek segíthetik a fiatalokat az élet azon problémáira való felkészülésben, amelyek központja a nemi késztetés, és amelyek valamilyen formában minden normális ember életében elkerülhetetlenül előfordulnak. E problémák az élettapasztalatok hatalmas sorára terjednek ki, a személyes szexuálhigiéné egyszerü kis ügyeitől a sikeres házasság és a családi viszonyok rendkívül bonyolult egészségügyi, szociálpszichológiai és erkölcsi problémáiig" (idézi Szilágyi, 2006. 25.).

6. A magyar Zrinszky László (2002. 190.) jóval egyszerübb definíciót használ a szexuális nevelésre: „mindazok a nevelési törekvések és hatások, melyek a nemi élet követendőnek tartott módjára vonatkoznak". Ez a definíció már felveti annak a szükségességét, hogy valaki/valakik (a nevelö? vagy valamilyen erre felhatalmazott közösség?) eldöntsék, mit tartanak a nemi élet „követendő módjának”, és annak megfelelően kell megtervezni a szexuális nevelést.

7. Olyan megközelítést is találtunk, ahol a kutatók a szexuális nevelés fogalmi meghatározását úgyszólván a kutatásban részt vevőkre bízzák. Egy nigériai kutatásban (ahol középiskolás diákokat, tanárokat és szülőket egyaránt megkérdeztek) feltették a kérdést, ki hogyan definiálná a szexuális nevelést (Orji és Esimai, 2003). Itt az alábbi 3 válaszlehetőségből lehetett választani, akár többet is megjelölve (továbbá a „,nem tudom” válaszlehetőség is adott volt):

- A diákok megtanítása arra, hogyan udvaroljanak, és hogyan éljenek szexuális életet.

- A diákok megtanítása a házasság előtti szex veszélyeire.

- A diákok megtanítása arra, hogyan kerüljék el a terhességet fogamzásgátlással.

Érdekes módon a szülők 60\%-a és a pedagógusok 54\%-a a „nem tudom” választ jelölte meg (talán épp azért, mert összetettebbnek tekintették a szexuális nevelés kérdését annál, semhogy a fenti válaszok bármelyikét is megfelelőnek találták volna), a diákok $65 \%$-a viszont megjelölte az első válaszlehetőséget. (Kétségtelen, hogy ez a válasz a 3 közül, amely a legtágasabban értelmezi a szexuális nevelést.)

Az imént bemutatott fogalmi megközelítések közül hozzám legközelebb a Kilanderféle definíció áll (nem véletlen, hogy a szexuálpedagógiával évtizedek óta foglalkozó magyar Szilágyi Vilmos is ezt a definíciót veszi át). Kilander megfogalmazása ugyanis jól érzékelteti nemcsak a témakör fontosságát, de annak tágasságát is. Ebbe a definícióba sok minden belefér, nem jelöli ki mereven a nemi nevelés határait, mégis eligazít, melyek azok a nevelési tartalmak, amelyeknek a szexuális nevelésben van a helyük.

Ezen a ponton érdemes feltennünk a kérdést: vajon ennek az átfogó, holisztikus nevelési területnek csakugyan a szexuális nevelés-e a legadekvátabb elnevezése? Abban a holisztikus megközelítésben ugyanis, amely a szexuálpedagógiát ma jellemzi, jóval

2 Az eredetiben: „Sex education is described as education about human sexual anatomy, sexual reproduction, sexual intercourse, reproductive health, emotional relations, reproductive rights and responsibilities, abstinence, contraception, family planning, body image, sexual orientation, sexual pleasure, values, decision making, communication, dating, relationships, sexually transmitted infections (STIs) and how to avoid them, and birth control methods." 
többről van szó, mint szexualitásról. Tulajdonképpen a párkapcsolati kultúra egésze van a nevelés fókuszában, amelynek természetesen fontos része a szexualitás is.

Magam részéröl ezért legadekvátabb elnevezésnek ma a párkapcsolati nevelést tartanám. (Ezzel együtt nem hagyhatjuk figyelmen kívül azt sem, hogy a szexualitás nemcsak a párkapcsolatokban jelenik meg. Mégis, talán érdemes a párkapcsolatok kérdését állítani a nevelés fókuszába.) Egyelőre azonban a nemzetközi szakirodalomban a szexuális nevelés az erre a nevelési területre leginkább használt fogalom.

\section{A szexuális nevelés kapcsolódása más nevelési területekhez}

A szexuális nevelés (vagy párkapcsolati nevelés) szorosan kapcsolódik a pedagógia számos más területéhez: például az erkölcsi neveléshez (hiszen a szexuális viselkedés rengeteg morális, etikai kérdést vet fel), az egészségneveléshez (elég a különféle, nem egyszer gyógyíthatatlan nemi betegségekre utalni) és a családi életre neveléshez.

Grósz Emese (2004) részletesen kifejti a szexuális nevelés kapcsolatát a pedagógia más területeivel. Az erkölcsi nevelés kapcsán megjegyzi, hogy szerinte „,nem a moralitás az, ami segít a „megfelelő” szexuális viselkedés kialakításában, hanem inkább a [...] fejlesztő-segítő nevelési attitüd" (Grósz, 2004. 45.). Ez azonban megítélésem szerint inkább módszertani kérdés: lehet vitatkozni azon, hogy az erkölcsi nevelésnek mi a leghatékonyabb formája, de nem megkerülhető, hogy a pedagógus törekedjen valamilyen (akár áttételes) módon erkölcsi normák, vagy legalábbis erkölcsi érzékenység kialakítására a szexualitás terén is. Kár volna tehát a szexuális nevelést teljesen elválasztani az erkölcsi neveléstöl.

Az egészségneveléshez való kapcsolódás nyilvánvaló: Grósz szerint a harmonikus partnerkapcsolat és az ehhez kapcsolódó egészséges nemi élet része az egészséges életmódnak, különösen, ha az egészséget testi-lelki-szociális értelemben értjük. Az egészségnevelésnek így mindenképpen szerves része (kellene, hogy legyen) a szexuális nevelés.

\section{A családi életre nevelés}

bizonyos tekintetben tágabb, bizonyos tekintetben szükebb a nemi nevelésnél. Úgy fogalmazhatunk, hogy a két területnek nagy a közös halmaza. A családi életre nevelés olyan témákkal is foglalkozik (pl. a családi gazdálkodás kérdései), amelyeket talán eróltetett volna a nemi nevelésbe beilleszteni. Ugyanakkor a párkapcsolat, szexualitás nemcsak a családi élet vagy az arra való elókészület részeként jelenik meg. Számos fiatal van ugyanis, aki akár egyáltalán nem kiván családot alapítani, ez azonban nem jelenti azt, hogy a párkapcsolatra, szexualitásra való felkészitésre ne lenne szüksége.

Grósz szerint a legújabb (ez nem feltétlenül jelenti azt, hogy a legadekvátabb) szexuálpedagógiai megközelítés a magánéleti nevelés keretében képzeli el a szexuális nevelést. Más kérdés, hogy a magánélet elválaszthatatlan a családi élettól, az egészséges életmódtól, illetve az erkölcsös/erkölcstelen élet kérdésétól, ilyen értelemben a magánéleti nevelés éppúgy szorosan kapcsolódik a fentebb emlitett nevelési területekhez. 
A családi életre nevelés bizonyos tekintetben tágabb, bizonyos tekintetben szükebb a nemi nevelésnél. Úgy fogalmazhatunk, hogy a két területnek nagy a közös halmaza. A családi életre nevelés olyan témákkal is foglalkozik ( $\mathrm{pl}$. a családi gazdálkodás kérdései), amelyeket talán erőltetett volna a nemi nevelésbe beilleszteni. Ugyanakkor a párkapcsolat, szexualitás nemcsak a családi élet vagy az arra való előkészület részeként jelenik meg. Számos fiatal van ugyanis, aki akár egyáltalán nem kíván családot alapítani, ez azonban nem jelenti azt, hogy a párkapcsolatra, szexualitásra való felkészítésre ne lenne szüksége.

Grósz szerint a legújabb (ez nem feltétlenül jelenti azt, hogy a legadekvátabb) szexuálpedagógiai megközelítés a magánéleti nevelés keretében képzeli el a szexuális nevelést. Más kérdés, hogy a magánélet elválaszthatatlan a családi élettől, az egészséges életmódtól, illetve az erkölcsös/erkölcstelen élet kérdésétől, ilyen értelemben a magánéleti nevelés éppúgy szorosan kapcsolódik a fentebb említett nevelési területekhez.

\section{Korszerü nemi nevelés?}

A szexuális neveléssel (vagy párkapcsolati neveléssel) kapcsolatban felmerül egy alapvető kérdés: mit tekinthetünk ma (a 21. század elején), Magyarországon korszerü nemi nevelésnek?

Ennek megválaszolásához rendelkezésünkre állnak nemzetközileg kidolgozott irányelvek (ld. később), mégis (a megfogalmazás rövidsége és frappánssága miatt) egy magyar szakember meghatározásával kezdjük (akinek a megközelítése egyébként összhangban van a nemzetközi iránymutatásokkal).

Szilágyi Vilmos (1997. 25.) így fogalmaz: „A korszerü nemi nevelés célja [...] a pszichoszexuálisan érett személyiség kialakítása, aki képes és kész a korszerü elveknek megfelelő életvezetésre. Ez utóbbi azt jelenti, hogy az egyén nemi magatartása, viselkedése a partnerkapcsolatban megfelel társadalmunk erkölcsi normáinak."

Szilágyi idézett rövid megfogalmazása elfogadható lehet sokféle pedagógiai irányzat számára, azonban két olyan kifejezést is használ, amelyet érdemes kissé körüljárnunk: mit jelent a „pszichoszexuálisan érett személyiség”, és mit értünk „társadalmunk erkölcsi normái” alatt? A következő két alfejezetben ezeket a fogalmakat igyekszünk körüljárni.

\section{A pszichoszexuális érettség}

A fogalom megértéséhez először a pszichoszexuális fejlődés fogalmát kell tisztáznunk, aztán foglalkoznunk kell az érett személyiség fogalmával, hogy utána összekapcsolhassuk ezt a kettöt.

A pszichoszexuális fejlődés fogalma a pszichoanalízist megteremtő Sigmund Freud nevéhez kötődik, aki munkássága során a 20. század elején többek között egy fejlődéslélektani elméletet is kidolgozott, amelynek középpontjában a pszichoszexuális fejlödés áll.

Az elmélet lényege röviden: a libidó (a legtágabb értelemben vett szexuális ösztönenergia) a gyermek fejlődése során más-más testrészre fókuszál. Egy későbbi, pszichoanalitikus szemléletü szakkönyv megfogalmazása szerint „a libidó szerveződésének időbeli sorrendje szerint határozzuk meg a gyermek pszichoszexuális fejlődésének fázisait (orális, anális-uretrális, fallikus, genitális fázis)" (Frenkl és Rajnik, 2007. 153.).

Freud elméletét már kortársai részéröl is sok kritika érte. A pszichoanalízis elméletének és terápiás gyakorlatának fejlődése során Freud tanítványai és követői is sok tekintetben vitatták, mások jelentősen átdolgozták, továbbfejlesztették ezt a fejlődéselméletet is. 
Az egyik sokszor megfogalmazott kritika, hogy Freud túl nagy jelentőséget tulajdonított a szexualitásnak, egyrészt a személyiségfejlődés, másrészt a különféle lelki betegségek kialakulásának tekintetében. Carl Gustav Jung például, aki, bár később szakított mesterével, Freud egyik legjelentősebb tanítványa volt, így fogalmaz: „A neurózis freudi szexuálteóriája igaz és valóságos princípiumra épül. De az egyoldalúság és kizárólagosság hibájába esik [...]. Freud ebből a szempontból is tipikus képviselője a materialista kornak" (Jung, 1993. 56-57.).

Erik H. Erikson, aki mindmáig igen széles körben elfogadott elméletet dolgozott ki a pszichoszociális fejlődésről, kifejezetten hangsúlyozza: „az emberi életciklus pszichoszociális elemzésére kidolgozott elgondolásaim Freud úttörő jelentőségü klinikai megállapításain alapulnak” (Erikson, 1997. 27.). Ugyanakkor később megjegyzi: „Freud [...] nem kerülhette el korának jellemző szemléleti vonzódásait” (uo. 29.), majd kifejti, milyen szemléleti korlátok jellemzik Freud és a korai pszichoanalitikusok müveit.

Szilágyi (2006) is leírja (a szexuálpszichológiai szakirodalomra építve), hogy erősen vitathatónak tartja a freudi koncepciót, elsősorban a fázisok merev, időbeni egymásutániságát.

Azonban a Freuddal szemben megfogalmazott kritikai észrevételek ellenére sok, a pszichoszexuális fejlődéshez kapcsolódó freudi alapfogalmat (pl. libidó, fallikus fázis stb.) használnak ma is a pszichológiában, elsősorban természetesen a modern pszichoanalízis különféle irányzatainak (a mai szaknyelv ezeket gyakran pszichodinamikus szemléletü irányzatoknak hívja) képviselői.

Hogyan viszonyulnak a pszichoszexuális fejlődés fogalmához más pszichológiai elméletek?

Justin J. Lehmiller (2014) bemutatja, milyen elméletek jelentek meg az évtizedek során, amelyek a pszichoanalitikus megközelítésekhez képest más tényezőket hangsúlyoznak a szexuális viselkedés kapcsán:

1. A tanuláselméleti modellek (klasszikus kondicionálás, operáns kondicionálás, szociális tanuláselmélet) közül legkorszerübbnek a szociális tanuláselmélet számít, amely a szexuális viselkedést alapvetően tanult viselkedésnek tartja, amelyben nagy szerepe van a mintakövetésnek. ${ }^{3}$ Ez az elmélet tehát szintén hangsúlyozza a szexualitás fejleszthetőségét, ezáltal a szexuális nevelés jelentőségét is.

2. A csereelméletek a kapcsolatokra vonatkozóan (és így a szexuális kapcsolatokra vonatkozóan is) azt hangsúlyozzák, hogy a kapcsolatokban mindig valamilyen csere történik (valamit adunk valamiért), és döntően ez határozza meg, hogyan müködnek a kapcsolatok. Ezek az elméletek kevésbé hangsúlyozzák a fejlődés jelentőségét a szexualitásban, bár nem is kérdőjelezik meg azt.

3. A személyiségelméletek azt vizsgálják a szexualitás kapcsán, mely személyiségvonások befolyásolják a szexuális viselkedést, és hogyan. Természetesen a személyiségjegyek is sok esetben a pszichés fejlődés során alakulnak ki, ez az elmélet sem cáfolja tehát a fejlődés jelentőségét a szexualitásban.

4. Az evolúciós elméletek pedig az evolúcióból kiindulva magyarázzák a szexuális viselkedés számos tényezőjét (ezen elméletek szerint például a férfiak tudattalanul azokhoz a nőkhöz vonzódnak, akik a külsejük alapján egészséges utódok kihordására képesek). Lehmiller megjegyzi, hogy ezek az elméletek nem tudnak választ adni számos kérdésre, például arra, hogy miért létezik homoszexualitás. ${ }^{4}$

3 „A pszichoszexuális fejlődést természetesen a tanuláselmélet hívei is egy hosszú folyamatnak látják, amely a születéssel kezdődik és a pszichoszexuális érettségben teljesedik ki” (Fábián és Simich, 2006. 13.)

4 A homoszexualitás lélektani hátterével kapcsolatos roppant bonyolult és egymással vitatkozó tudományos nézetek bemutatása meghaladja e tanulmány kereteit. Annyi azonban kijelenthető, hogy nincs tudományos konszenzus ezen a téren. 
Lehmiller hangsúlyozza, hogy a szexualitás korszerü megközelítése biológiai, pszichológiai és szociális tényezőket egyaránt figyelembe vesz, amikor a szexuális viselkedést magyarázni kívánja.

Ami számunkra fontos: alapvetően elfogadott a pszichológia különféle kortárs elméleteiben is, hogy az ember szexualitáshoz való viszonya fejlődés eredménye, és hogy ez a viszony szorosan összefügg egyéb pszichés jelenségekkel.

Az érett személyiség fogalmával a humanisztikus pszichológia prominens személyiségei, Abraham H. Maslow és Gordon W. Allport kezdtek érdemben foglalkozni. Mindketten megkísérelték az érett személyiség kritériumainak meghatározását. (Az ő megközelítésükre azóta is gyakorta hivatkoznak.)

Maslow történelmi személyiségek életútját vizsgálta, olyan emberekét, akik szerinte sikeresek voltak az önmegvalósításban, és akiket a közvélemény igen sokra tartott, akiket szerinte joggal tekinthetünk érett személyiségnek. Elemzései alapján 14 pontban foglalta össze az érett személyiség jellemzőit (Allport, 1997):

1. A valóság hatékony észlelése, kielégítő viszony a realitáshoz.

2. Elfogadás önmagunkkal, másokkal és a természettel szemben.

3. Spontaneitás.

4. Feladatközpontúság.

5. Távolságtartás. (A magánélet sérthetetlensége; a kapcsolatokban nincs jelen a birtoklás vágya.)

6. Függetlenség a kultúrától és a környezettől.

7. A befogadás állandó frissessége.

8. Végtelen horizontok. (Ez a legvégső kérdések iránti érdeklődést, a spirituális nyitottságot jelenti.)

9. Szociális érzékenység.

10. Mély, de szelektív társas kapcsolatok.

11. Demokratikus jellemszerkezet.

12. Etikai szilárdság.

13. Ellenségességtől mentes humorérzék.

14. Alkotóképesség (kreativitás).

Maslow kritériumrendszere talán túl részletes. Érdemes Allport kritériumait is felsorolnunk, ő tömörebben, kevesebb kritérium felállításával foglalta össze az érett személyiség jellemzőit. Fogjuk majd látni, hogy ezek a pszichoszexuális érettség később megfogalmazott kritériumaival szoros összefüggésben állnak.

Allport (1997) szerint az érett személyiség hat kritériuma:

1. az én érzésének kiterjesztése (azaz az önközpontúság meghaladása);

2. meghitt viszony másokkal;

3. érzelmi biztonság (önelfogadás);

4. valósághủ észlelés, jártasságok és feladatok;

5. az én tárgyiasítása, önismeret és humor;

6. az egységesító életfilozófia.

Hogyan viszonyul mindehhez a pszichoszexuálisan érett személyiség?

Most jutottunk el oda, hogy megfogalmazzuk: tulajdonképpen milyen személyiség kialakítására törekedjék a szexuális nevelés? Lássuk néhány megközelítését a pszichoszexuális érettségnek.

Szilágyi Vilmos (1997), támaszkodva a nemzetközi szexuálpszichológiai szakirodalomra, a pszichoszexuálisan érett személyiség elsődleges jellemzőjének az intimkapcsolatokra való alkalmasságot tartja (ez alakul ki hamarabb). A teljes pszichoszexuális 
érettséghez azonban hozzátartozik a párválasztási érettség is, amikor a párválasztásban benne van a véglegesség igénye, a családalapítás szándéka és képessége. Megfogalmazza azt is, hogy milyen tényezők megléte esetén tekinti érettnek a házasodási motivációkat:

- a reálisan mérlegelt összeillés,

- a gyermek iránti kölcsönös vágy,

- szerelem.

Grósz Emese (2004) hasonlóan vélekedik. Szerinte a pszichoszexuális érettség kritériumai: képesség a családalapításra és az érett házaséletre. Ez a megfogalmazás roppant egyszerünek tünik, ne feledjük azonban, hogy az érett házasélet számos készséget és képességet igényel (pl. az együttmüködés, a kommunikáció, az alkalmazkodás, a felelösségvállalás stb. terén).

Az eddigieket is magában foglaló, de azoknál teljesebb megfogalmazás a lengyel Lew-Starowiczé (1985). Szerinte az érett személyiség magában foglalja a pszichoszexuális érettséget is, bár megjegyzi, hogy kultúránkban nem ritka az olyan ember, akinek személyisége számos területen érett, a pszichoszexuális érettség még sincs meg benne. A pszichoszexuális érettség kritériumaiként az alábbiakat írja le:

- tartós érzelmi kapcsolat képessége a másik nemhez tartozóval;

- a saját nőiesség/férfiasság fejlesztése, tudatos viszony a nemiséggel;

- felelősségvállalás (önmagunkért és a másikért), a másik ember egyenlő félként való kezelése;

- a saját szexuális szükségletek feletti uralkodás képessége.

Forrai Judit, amikor a pszichoszexuális érettségről ír (1993), felsorolja az összes kritériumot, amely Lew-Starowicznál szerepelt, kiegészítve azokat még két kritériummal:

- felelösségvállalás azért, hogy a partner is szexuális önkontrollal bírjon;

- stabil énkép.

A fenti megfogalmazások között sok átfedés van, érzékelhetően hasonlóképpen értelmezik a pszichoszexuálisan érett személyiség fogalmát, még ha vannak is hangsúlybeli különbségek (például abban, hogy mennyiben kapnak morális színezetet a megfogalmazott kritériumok).

Ha választani kell, összességében talán Lew-Starowicz kritériumrendszere áll hozzám legközelebb. ${ }^{5}$ (Fogjuk majd látni, hogy összhangban van ez a kritériumrendszer a WHO által néhány éve kiadott, szexuális nevelésre vonatkozó európai irányelvekkel is.)

Láthatjuk azt is a különböző megfogalmazásokból, hogy a pszichoszexuálisan érett személyiség és az Allport kritériumrendszere szerint érettnek tekintett személyiség tulajdonságai csakugyan számos összefüggést mutatnak.

Allport első kritériuma az önközpontúság meghaladása. Ehhez tartozik a másikért való felelősségvállalás is, amit a pszichoszexuális érettség fontos részének tart Lew-Starowicz. A második kritérium Allportnál a másokkal való meghitt viszony. A pszichoszexuális

5 Ezen a ponton ismét felmerül a homoszexualitás kérdése, hiszen a lengyel szakember ,,a másik nemhez tartozó" partnerrel való tartós érzelmi kapcsolatról beszél. A pszichológiában és más tudományokban is folyó (már korábban is említett) igen éles, ráadásul gyakran politikai, filozófiai vagy vallási ideológiákkal telített viták kereszttüzében nagyon nehéz állást foglalni abban a kérdésben, hogy a homoszexuális emberek esetében mik a pszichoszexuális érettség kritériumai. Erre ebben a dolgozatban nem vállalkozunk. Mindenesetre a heteroszexuális emberek esetében mindenképpen elfogadhatónak tartjuk Lew-Starowicz kritériumait. A homoszexuális vagy más szexuális kisebbséghez tartozó fiatalkorúak nemi neveléséről egyébként nemrég jelent meg 2 részletben egy magyar nyelvü tanulmány (Somorjai, 2016). A szerző úgy látja (amerikai kutatási eredmények alapján), hogy az intézményes szexuális nevelés egyáltalán nem szentel figyelmet a kérdésben érintett serdülökre. 
érettség megközelítéseinél több helyen is szerepelt az intim kapcsolatokra való képesség. Az érzelmi biztonság, önelfogadás (Allport harmadik kritériuma) szorosan összefügg a stabil énképpel, ami Forrai Judit szerint szintén hozzátartozik a pszichoszexuális érettséghez.

Így az is kijelenthető, hogy a korszerünek tekinthető szexuális nevelés célkitüzései jól illeszkedhetnek az általában vett érett személyiség kialakítására törekvő nevelési koncepciókhoz. Vagyis ha úgy gondoljuk, hogy a nevelés egyik fontos célja az érett személyiség kialakítása (személy szerint ezen az állásponton vagyok), akkor ebbe a pedagógiai elképzelésbe jól beilleszthető a fenti megfontolások alapján korszerünek tekintett szexuális nevelés is.

\section{Erkölcsi normák a szexualitásban}

A korszerü nemi nevelés fenti meghatározásában szerepelt az is, hogy kívánatos lenne, ha a szexuális nevelés hatására az egyén viselkedése a partnerkapcsolatokban megfelelne „társadalmunk erkölcsi normáinak”.

Természetesen nem egyszerű meghatározni, melyek a 21. század elején ezek a normák. Akár azt is mondhatnánk, hogy korunkban (a posztmodern vagy poszt-posztmodern korban) egyáltalán nem beszélhetünk egységes erkölcsi normákról a társadalomban (legfeljebb bizonyos területeken), de azért érdemes körüljárnunk a kérdést. Melyek tehát azok az erkölcsi normák, amelyek átadására törekednie érdemes az iskolai szexuális nevelésnek?

Hallstead és Reiss (2003) egész könyvet szenteltek a szexuális nevelés különféle megközelítéseiben megjelenő értékek, értékrendek (pl. liberális értékek, vallásos értékek stb.) bemutatásának és azok elemzésének. A szerzők világossá teszik, hogy a szexuális nevelés mindig valamilyen értékek mentén zajlik (akár tudatos ez, akár nem). Teljesen értéksemleges szexuális nevelésröl ebben az értelemben nem beszélhetünk. Ezek az értékek pedig a képviselt erkölcsi normákat is erőteljesen meghatározzák. (Ez is alátámasztja azt, amit korábban írtunk: a szexuális nevelést nem tudjuk elválasztani az erkölcsi neveléstől.) Viszont egyértelműen kijelenthető összefoglalásuk alapján az is, hogy nincs társadalmi konszenzus a szexuális nevelésben megjelenítendőnek tartott értékek és erkölcsi normák tekintetében.

Castleman (2006) szerint a liberális és a konzervatív tábor évtizedek óta harcban áll egymással a szexuális nevelés szerepét, céljait illetően. Nem meglepő módon éppen az erkölcsi normák terén van a legnagyobb különbség a két tábor felfogása között (pl. a müvi abortusz erkölcsi megítélésében). Nyilvánvalóan nehéz így egységes erkölcsi normákról beszélni társadalmi szinten, legalábbis a szexualitás terén. Ez természetesen az iskolai szexuális nevelés számára is kihívást jelent.

Tegyük hozzá ehhez, hogy a klasszikus konzervatív és liberális felfogás mellett, elsősorban az angolszász pedagógiai gondolkodásban fontos irányzattá vált egy „harmadik út”, a kritikai pedagógia, amely mindkét nagy irányzattal vitában van. Mészáros György tanulmánya részletesen bemutatja a kritikai pedagógiai diskurzust, és hogy milyen pontokon vitázik a konzervatív és a liberális pedagógiával (Mészáros, 2005). A kritikai pedagógia érzékenyen reflektál mindarra, ami a nevelési folyamatban normaként jelenik meg, hiszen ez az irányzat épp azt tartja problémásnak, ha a pedagógiai tevékenység újratermeli a társadalmi igazságtalanságokat, többek között a társadalmi normák közvetítése által. Ezzel tovább bonyolódik a helyzet, hiszen ezáltal nemcsak az válik kérdésessé, hogy mik „társadalmunk erkölcsi normái” (pl. a szexualitással kapcsolatban), hanem az is, hogy helyes-e egyáltalán a társadalmi normák közvetítésére törekedni a nevelésben.

Ugyanakkor többek között a kritikai pedagógiának is köszönhető, hogy a szexuális nevelés témája a neveléstudományban nagyobb figyelmet kapott: „A pedagógia általában 
keveset foglalkozik a test, a vágyak, az érzelmek, a szexualitás világával. A kritikai irányzat azonban a neveléstudományi kutatás teljes jogú, fontos témaköreinek tekinti, és gyakran szól ezekről a témákról" (Mészáros, 2005. 96.).

Érdemes itt szólni arról is, hogy a kritikai pedagógiára erős hatást gyakorolt többek között Michel Foucault filozófiája. Foucault háromkötetes nagy munkát szentelt a szexualitás történetének, és ennek a munkának a fókuszában a szexualitás és a hatalom viszonya áll. Idézzünk egy jellemző gondolatot a müből: „Aki a szexualitásról beszél, bizonyos mértékig kivonja magát a hatalom fennhatósága alól; megkérdőjelezi a törvényt; $s$ ha csak csipetnyit is, megelölegzi az eljövendő szabadságot" (Foucault, 1996. 10-11.). Foucault gondolatainak hatása mindenképpen meghatározó a kritikai pedagógia szexuális nevelés iránti érdeklődésében.

Hogyan gondolkodnak erről a kérdésröl a magyar szakemberek?

Szilágyi (2006) úgy látja, a nemi nevelés erkölcsi normáit a humanizmus értékrendjéből kell merítenünk. ${ }^{6}$ Ö így értelmezi ezt: „A humanista szexuáletika [...] nem kívánja saját normatíváit sem természetfölötti, sem más tekintélyekre hivatkozva szentesíteni, vagy abszolút jellegüeknek feltüntetni, hanem igyekszik azokat a társadalom lényeges (bár változó) érdekeire alapozni” (Szilágyi, 2006. 34-35. o.). A kérdés azonban az, hogy ki van felhatalmazva arra, hogy eldöntse, mik a társadalom érdekei? A különféle szakemberek, társadalomtudósok, politikusok stb. sokszor egymással homlokegyenest ellenkező dolgokat tekintenek társadalmi érdeknek. Hogyan lehetne hát egységes álláspontra jutni ezen a téren? Erre a kérdésre nehéz megnyugtató választ adni.

Egy korábbi írásában Szilágyi (1997. 25.) így fogalmaz: „Az erkölcsileg értékes nemi kapcsolat fö kritériumait a következőkben összegezhetjük: legyen egyenjogú partnerek
A kritikai pedagógia érzékenyen reflektál mindarra, ami a nevelési folyamatban normaként jelenik meg, hiszen ez az irányzat épp azt tartja problémásnak, ha a pedagógiai tevékenység újratermeli a társadalmi igazságtalanságokat, többek között a társadalmi normák közvetítése által. Ezzel tovább bonyolódik a helyzet, hiszen ezáltal nemcsak az válik. kérdésessé, hogy mik „társadalmunk erkölcsi normái" (pl. a szexualitással kapcsolatban),

hanem az is, hogy helyes-e egyáltalán a társadalmi normák közvetítésére törekedni a nevelésben.

Ugyanakkor többek között a kritikai pedagógiának is köszönhetố, hogy a szexuális nevelés témája a neveléstudományban nagyobb figyelmet kapott: „A pedagógia általában keveset foglalkozik a test, a vágyak, az érzelmek, a szexualitás világával. A kritikai irányzat azonban a neveléstudományi kutatás teljes jogú, fontos témaköreinek tekinti, és gyakran szól ezekról a témákról” (Mészáros, 2005. 96.).

6 Frederick Edwords, a kortárs amerikai humanizmus egyik meghatározó alakja egy előadásában figyelmeztet, hogy a „humanizmus” szónak sok jelentése van, és akik erről írnak vagy beszélnek, nem mindig teszik egyértelművé, melyik jelentésre gondolnak (http://americanhumanist.org/humanism/what_is_humanism). Ez a kritikai észrevétel Szilágyi esetében is felvethetö. 
szabad, önként és felelősségtudattal vállalt, kölcsönösen előnyös és fejlesztő hatású kapcsolata, amely figyelembe veszi a társadalom lényeges érdekeit is".

Miksa Lajos szerint (2005) a „liberális szexuálpedagógia” (nem hivatkozik konkrét szerzőkre) három követelményt támaszt az erkölcsös nemi viszonnyal szemben: legyen önkéntes, egyenrangú és kölcsönös. Ezeket a szempontokat jónak tartja, de nem elegendőnek. Ezekhez hozzátesz (Erich Frommra hivatkozva) négy tényezőt: törődés, felelősség, tisztelet és ismeret. Itt is megjelenik a Castleman által elemzett konzervatív-liberális szembenállás (nem biztos, hogy Miksa Lajos magát konzervatívnak nevezi, de az kiderül a szövegből, hogy feltételezi valamifajta egységes liberális szexuálpedagógia meglétét, és részben ezzel szemben határozza meg saját álláspontját).

Vajon a fentebb idézett Szilágyi-féle kritériumokból (valószínűsíthetően Miksa őt is a liberális szexuálpedagógusok közé sorolja, hiszen Szilágyi számos tekintetben igen megengedő nézeteket vall a szexuális viselkedés terén) csakugyan hiányoznak Fromm szempontjai? Hiszen a „felelősség” megjelenik Szilágyinál is. A „törődés”, „tisztelet” és „szeretet” szavak pedig ugyan nem jelennek meg nála explicit formában, de ha egy pár törekszik arra, hogy nemi kapcsolatuk csakugyan „,kölcsönösen elönyös és fejlesztő hatású" legyen, ahogy Szilágyi fogalmaz, az feltételezi, hogy törődés, tisztelet és szeretet legyen bennük egymás iránt. Ilyen értelemben Miksa liberális szexuálpedagógusokra vonatkozó általánosító kritikája (legalábbis Szilágyi vonatkozásában) nem állja meg a helyét.

Szilágyi imént idézett kritériumait (az erkölcsileg értékes nemi kapcsolatról) minden bizonnyal sokan elfogadnák a konzervatívabb szexuálpedagógusok közül is. Amiben vélhetőleg igazán nagy különbség lenne: ki mikor tekinti a szexuális kapcsolatot „előnyösnek” és „fejlesztő hatásúnak”? Lehet-e például fejlesztő hatású a házasság előtti vagy házasságon kívüli szexuális kapcsolat? Szilágyi Vilmos írásaiban egyértelmüvé teszi, hogy ő igenlő választ ad erre a kérdésre. Számos szerző azonban (pl. Tomka, 2010; Varga, 2007; Tárkányi, 2011) amellett érvel, hogy a házasság előtti szexuális kapcsolatnak inkább káros hatásai vannak (meg kell jegyeznünk, ez utóbbiak jellemzően keresztény világnézetü szerzők). Hogyan lehetne ezek után egységes erkölcsi normákról beszélni?

Részben az erkölcsi normák terén meglévő, fent részletezett különbségek miatt gyakorlatilag elképzelhetetlen, hogy a magyarországi iskolák a szexuális nevelés terén teljesen egységes célokat tüzzenek ki. Arra azonban lehet esély, hogy a szexuálpedagógiával foglalkozó szakemberek megállapodjanak az iskolai szexuális nevelésben képviselhető erkölcsi normák terén egy olyan közös minimumban, amely minden magyarországi iskola számára elfogadható, és amelyet aztán az egyes iskolák tetszés szerint bővíthetnek, akár szigoríthatnak.

Nagyon találó, amit ezzel kapcsolatban Zrinszky László (2002. 194.) ír: „Ilyen körülmények között a szexuális nevelés sem egységes. De bármilyen etikai, pszichológiai és egészségügyi meggondolások domináljanak is benne, keresi azokat a pedagógiai megoldásokat, melyek nem veszik semmibe a tradicionális értékfelfogást, ugyanakkor igyekeznek megfelelni a 21. század új kihívásainak is”.

\section{A korszerü nemi nevelés céljai és alapelvei}

Milyen célokat és alapelveket tüzhet ki maga elé a szexuális nevelés, amennyiben korszerüségre törekszik? Az utolsó alfejezetben ezt vizsgáljuk.

Az elmúlt évtizedekben fontos külföldi szervezetek fogalmaztak meg a szexuális neveléssel kapcsolatos célkitüzéseket. Az Egyesült Államok Szexuális Nevelési Tanácsa (SIECUS) pl. még a kilencvenes években kidolgozott egy útmutatót az átfogó szexuális 
neveléshez (magyar nyelven ennek összefoglalását közli pl. Asztalos és Nagyné, 2012). Kanadában szintén megszületett egy hasonló dokumentum a szexuális nevelésre vonatkozó irányelvekről.

Még fontosabbak azonban a nemzetközi szervezetek által kidolgozott iránymutatások. Az UNESCO 2009-ben adta ki a már korábban említett nemzetközi útmutatóját a szexuális neveléshez (International Technical Guidance, 2009). Az útmutatót hosszas elökészítő munka előzte meg: kutatásokat végeztek a világ számos országában, és számos szakértőt vontak be a munkába.

A célokat illetően így fogalmaz a szöveg: „A szexuális nevelés elsődleges célja, hogy a gyerekek és a fiatalok fel legyenek vértezve tudással, készségekkel és értékekkel ahhoz, hogy felelős döntéseket tudjanak hozni szexuális és társas kapcsolataikról” (3. o.; saját fordítás).

Leírják továbbá, hogy a szexuális nevelési programok többnyire az alábbi célokat tüzik ki:

- Növelni a tudásszintet és a megértést.

- Megmagyarázni és tisztázni az érzéseket, értékeket és attitüdöket.

- Készségeket fejleszteni vagy megerősíteni.

- Elősegíteni és fenntartani a kockázatcsökkentő viselkedést.

Az útmutató ezután hosszan sorolja a hatékonynak bizonyult szexuális nevelési programok jellegzetességeit.

Néhány éve európai irányelveket is kidolgoztak. A WHO (Egészségügyi Világszervezet) Európai Regionális Irodája és a németországi BZgA (Szövetségi Egészségnevelési Központ, Köln) 2010-ben adott ki egy fontos dokumentumot Az európai szexuális nevelés irányelvei. Vázlat a politikusok, nevelési és egészségügyi intézmények és szakemberek részére címmel. Ezt a dokumentumot számos európai országból összehívott, a szexuális nevelés terén tapasztalt szakemberek alkották meg. Ennek 4. fejezetét (A szexuális nevelés alapelvei és eredményei) a szokásosnál kicsit hosszabban idézem.

„A holisztikus szexuális nevelésnek a következő alapelvekre kell épülnie:

1. A szexuális nevelés számol a gyermek életkorával, fejlettségi és értelmi szintjével, s reagál annak kulturális és szociális körülményeire és szociálpszichológiai nemére (gender). Vagyis alkalmazkodik a fiatalok valóságos életéhez.

2. A szexuális nevelés a (szexuális és reproduktív) emberi jogokon alapul.

3. A szexuális nevelés a jól-lét holisztikus koncepcióján alapul, amely az egészséget is magában foglalja.

4. A szexuális nevelés alapvetőnek tartja a nemek egyenlőségét, az önmeghatározást és a különbségek elfogadását.

5. A szexuális nevelés a születéssel kezdődik.

6. A szexuális nevelés az egyének és közösségek fejlesztésével hozzájárul egy igazságos és szolidáris társadalom létrehozásához.

7. A szexuális nevelés tudományosan megalapozott ismereteken alapul." (WHO BZgA, 2010.)

Időzzünk el egy kicsit a felsorolt alapelveknél. Ez a dokumentum, mint látjuk, a „holisztikus" (vagyis egészleges, teljességre törekvő) kifejezést használja a szexuális nevelésre nézve, ami szinkronban van a szexuális nevelésnek azzal a tágas, átfogó megközelítésével, amit a kortárs szexuálpedagógiai kutatók többsége képvisel (ld. fent). Számos olyan dolog megjelenik az alapelvek között, amelyek tulajdonképpen a fejlett nyugati világ alapértékei közé tartoznak: az emberi jogok tisztelete, a nemek közti egyenlőség, a tolerancia, az igazságos és szolidáris társadalom stb. Ezek az elvek éppen ezért valóban irányadók lehetnek Európa egészére nézve. 
A szöveg így folytatódik:

„A szexuális nevelés a következő eredményekre törekszik:

1. Egy olyan szociális légkör elősegítése, amely toleráns, nyitott és megbecsülést tanúsít a nemiség, a különböző életstílusok, attitüdök és értékek iránt.

2. A nemi különbségek és a gender sokféleség tiszteletben tartása, valamint a nemi identitás és a nemi szerepek tudatosítása.

3. A körültekintő és a helyzet megértésén alapuló választások képességének kialakítása, s így felelős viselkedés önmagával és a partnerrel szemben.

4. Ismerni az emberi testet, annak fejlődését és funkcióit, főleg a nemiség vonatkozásában.

5. A nemi lényként fejlődés képessége, vagyis az érzelmek és szükségletek kifejezése, a nemiség kellemeskénti megélése, azonkívül a saját nemi identitás és nemi szerep kialakítása.

6. Elegendő információval rendelkezés a nemiség, a fogamzásgátlás, a nemi úton terjedő fertőzések (köztük a HIV) és a nemi erőszak megelőzésének testi, kognitív, szociokulturális és emocionális vonatkozásairól.

7. Rendelkezés minden, a szexuális kapcsolatok megfelelő kezeléséhez szükséges készséggel.

8. Tájékozottság a tanácsadó és orvosi szolgálatok elérhetőségéröl, különösen a szexualitással kapcsolatos kérdések és problémák felmerülése esetén.

9. A szexualitással kapcsolatos, különböző normák és modellek értékelése az emberi jogok szempontjából, a saját kritikai attitüdök kialakítása érdekében.

10. Olyan (szexuális) kapcsolatok létesítésének képessége, amelyekre egymás igényeinek és kötöttségeinek kölcsönös megértése és tiszteletben tartása, vagyis egyenlőség jellemző. Ez elősegíti a szexuális visszaélések és erőszak megelőzését.

11. Képesség a szexualitás, az érzelmek és kapcsolatok megbeszélésére, az ehhez szükséges, közérthető nyelven.” (WHO - BZgA, 2010.)

Az alapelvek kapcsán kiemelt európai alapértékek (az emberi jogok tisztelete, a nemek közti egyenlőség, a tolerancia) természetesen itt is visszaköszönnek. Mindezeknek kétségkívül vannak erkölcsi vonatkozásai is, ráadásul a szöveg egyéb erkölcsi értékeket is kiemel: pl. felelősség, egymás értékeinek tiszteletben tartása. A dokumentum szerzői tehát nem hagynak kétséget afelöl, hogy álláspontjuk szerint a szexuális nevelésnek nemcsak információk átadására (a 4., 6. és 8. pont elsősorban erre vonatkozik) és képességek kialakítására (ld. 3., 5., 7., 9., 10., 11. pontok) kell törekednie, de bizonyos erkölcsi értékek átadására is.

Úgy gondolom, az összehívott szakembereknek valóban sikerült olyan alapelveket és kívánatos eredményeket megfogalmazni a szexuális nevelés kapcsán, amelyek az európai szexuálpedagógia egésze számára elfogadhatóak lehetnek. (Ez még akkor is igaz, ha nem hagyhatjuk figyelmen kívül azokat a különbségeket, amelyeket a szexuálpedagógusok által képviselt erkölcsi normák kapcsán fentebb megvizsgáltunk.)

Ugyanakkor Európa mai helyzetéröl gondolkodva nem hagyhatjuk figyelmen kívül azt a tényt, hogy Nyugat-Európa több országában is (pl. Németország, Franciaország, Egyesült Királyság) egyre nagyobb iszlám közösségek élnek. Az iszlám vallású gyermekek esetében az iskolai szexuális nevelés újabb dilemmákat vet fel. Az iráni származású szexológus, Alireza Tabatabaie, aki jelenleg a cambridge-i egyetemen tanít, felhívja a figyelmet rá, hogy a muszlimok körében a gyermekek és serdülők szexuális nevelését általában kifejezetten ellenzik (Tabatabaie, 2015). Ezért azokban az iskolákban, ahová muszlim diákok is járnak, fokozott óvatossággal kell a szexuális nevelést megtervezni. Semmiképp nem megkerülhetö például, hogy a pedagógusok egyeztessenek a szülőkkel a szexuális nevelés kapcsán. 
Tulajdonképpen a multikulturális nevelés problematikája jelenik meg ebben, amely természetesen nemcsak az európai iszlám közösségek kapcsán ad kihívásokat a pedagógiai intézményrendszernek.

Ez a probléma Magyarországot egyelőre kevéssé érinti, nem tudhatjuk azonban, hogy a jelenlegi, Európa egészét érintő menekültválság következményeként hogyan alakul a következő években Magyarország etnikai és vallási összetétele.

Nézzük meg itt is, hogy látják a korszerü szexuális nevelés céljainak és alapelveinek kérdését a magyar szakemberek!

Szilágyi Vilmos szerint a korszerü szexuális nevelés négy célt tüz maga elé:

1. megbízható ismeretek, információ átadása (a szexualitáshoz kapcsolódó témakörökben);

2. a különféle szexuális attitüdök és értékrendek megismertetése;

3. a kapcsolatépítés és -fenntartás készségeinek fejlesztése;

4. a felelősségteljes szexuális viselkedés gyakorlatának elősegítése.

Mint az 1. táblázatból látszik: ha nem is szó szerint ugyanaz a megfogalmazás, de szinte ugyanazt a 4 célt fogalmazza meg Szilágyi, mint amelyek az UNESCO kiadványában szerepelnek a szexuális nevelési programok céljaiként.
Ugyanakkor Európa mai helyzetéról gondolkodva nem hagyhatjuk figyelmen kivïl azt a tényt, hogy Nyugat-Európa több országában is (pl. Németország, Franciaország, Egyesült Királyság) egyre nagyobb iszlám közösségek élnek. Az iszlám vallású gyermekek esetében az iskolai szexuális nevelés újabb dilemmákat vet fel. Az iráni származású szexológus, Alireza Tabatabaie, aki jelenleg a cambridge-i egyetemen tanit, felhíja a figyelmet rá, hogy a muszlimok körében a gyermekek és serdülók szexuális nevelését általában kifejezetten ellenzik (Tabatabaie, 2015). Ezért azokban az iskolákban, ahová muszlim diákok is járnak, fokozott óvatossággal kell a szexuális nevelést megtervezni. Semmiképp nem megkerülhetố például, hogy a pedagógusok egyeztessenek a szülókkel a szexuális nevelés kapcsán.

1. táblázat. A szexuális nevelési programok céljai

\begin{tabular}{|l|l|}
\hline \multicolumn{1}{|c|}{ UNESCO (2009) szerint } & \multicolumn{1}{c|}{ Szilágyi Vilmos (2006) szerint } \\
\hline Növelni a tudásszintet és a megértést. & Megbízható ismeretek, információ átadása. \\
\hline $\begin{array}{l}\text { Megmagyarázni és tisztázni az érzéseket, } \\
\text { értékeket és attitüdöket. }\end{array}$ & $\begin{array}{l}\text { A különféle szexuális attitüdök és értékrendek } \\
\text { megismertetése. }\end{array}$ \\
\hline Készségeket fejleszteni vagy megerősíteni. & $\begin{array}{l}\text { A kapcsolatépítés és -fenntartás készségeinek } \\
\text { fejlesztése. }\end{array}$ \\
\hline $\begin{array}{l}\text { Elősegíteni és fenntartani a kockázatcsökkentő } \\
\text { viselkedést. }\end{array}$ & $\begin{array}{l}\text { A felelösségteljes szexuális viselkedés } \\
\text { gyakorlatának elösegítése. }\end{array}$ \\
\hline
\end{tabular}

Az utolsó pontban van egyedül számottevő különbség: a felelösségteljes szexuális viselkedés ugyanis többet jelent, mint a kockázatok csökkentését, bár nyilvánvalóan az is része. 
Szilágyi megfogalmaz bizonyos tartalmi alapelveket a korszerü szexuális nevelés kapcsán. Ilyen alapelvek:

- A szexualitás az élet természetes és értékes velejárója.

- A szexuális viselkedés tanítható és tanulható.

- Az erkölcsi normák tekintetében a humanizmus értékrendje az irányadó (ld. fentebb).

Itt megjegyeznénk, hogy az első 2 alapelvvel nincs vitánk, a szexuális viselkedés tanulhatóságát a korábban bemutatott pszichológiai elméletek is kellően igazolják. Az erkölcsi normák tekintetében viszont már bemutattuk, hogy nem annyira egyszerü ez a kérdés, mint ahogy ebből a megfogalmazásból gondolnánk.

A szexuális nevelés módszertani alapelvei pedig Szilágyi szerint a következők:

1. folyamatosság, bővítés és elmélyítés;

2. az életkori, nemi és egyéni sajátosságok figyelembevétele;

3. aktív előkészítés és immunizálás (ne várjuk passzívan, amíg a gyerek kérdez);

4. felvilágosítás és jellemnevelés egysége;

5. személyes kapcsolat, bizalom és őszinteség;

6. közösség és koedukáció (ez nem zárja ki, hogy esetenként egyéni vagy nemek szerinti foglalkozást is tartsunk);

7. szakszerüség, tárgyilagosság és világosság;

8. személyes példamutatás, természetesség és kongruencia;

9. munkamegosztás és koordináció (ne csak az iskola vegyen benne részt, hanem a család, az egészségügyi és egyéb intézmények, valamint a média is);

10. felelősségre nevelés (Szilágyi, 2006. 31-37.).

Megítélésem szerint ezek az elvek ugyan nem mind tisztán módszertani jellegűek (pl. a felelősségre nevelést nem módszertani kérdésnek, inkább nevelési célkitüzésnek tekinthetjük), de mindenesetre elég árnyalt szempontrendszert adnak a szexuális neveléshez.

Ha összevetjük a Szilágyi által felsorolt módszertani alapelveket a WHO ajánlásaival, azt látjuk, hogy a 2., a 7. és 10. alapelv explicit formában szerepel a WHO ajánlásában is (vö. a WHO által felsorolt alapelvek között az 1. és 7. ponttal, illetve az eredmények között a 3. ponttal), a 4. alapelv pedig szintén kiolvasható a WHO ajánlások egészéböl.

A Szilágyi által felsorolt többi alapelv számos fontos pedagógiai szempontot tesz hozzá a szexuális nevelés gyakorlati megvalósításához. Láthatjuk, hogy Szilágyi erőteljesen hangsúlyozza pl. a pedagógus személyes képességeit, attitüdjeit is (5. és 8. alapelv), valamint az iskolai szexuális nevelés közösségi jellegét. Továbbá Szilágyi hangsúlyozza azt is, hogy együttmüködés szükséges az iskola és a nevelés egyéb színterei között. (Egyébként a WHO dokumentumának 6. fejezetében, amikor a szöveg a szexuális nevelés gyakorlati megvalósítását kezdi részletezni, megjelennek ezek a szempontok is.)

Nézzünk meg egy másik magyar megközelítést is: Berend és Péterfia (1998. 12-14.) a családi életre nevelés tantárgy tanári kézikönyvében azt írják, hogy a családi életre nevelés tantárgy (amelynek tematikáját Czeizel Endre dolgozta ki) a következő alapértékek mentén szerveződik (amelyekből megfogalmazhatók a nevelési célok is):

1. a család, mint a társadalom elemi sejtje;

2. a háromgyermekes családmodell elsődlegessége;

3. a boldog, kiegyensúlyozott, tabuktól, megszorításoktól mentes, örömszerző nemi élet;

4. spontaneitás helyett tudatosság a szexuális életben;

5. a szexuálisan terjedő betegségek legyőzése;

6. optimális családtervezés. 
Érdemes az itt felsorolt 6 alapértéket szintén összevetni a WHO ajánlásaival. Ezúttal a 3 ., a 4. és az 5. alapérték található meg közvetlenül a WHO ajánlásaiban (vö. az eredmények között elsősorban a 3., 5. és 6. pontokat). Az 1., 2. és 6. alapérték szorosabban a családi élethez kapcsolódik. A WHO ajánlásaiban azonban (mondhatnánk, a politikai korrektség jegyében) a család kifejezést (és a családdal kapcsolatos bármiféle értékelvü állítást) végig kerülik, érthető hát, ha ezek az alapértékek abban a szövegben nem jelennek meg.

A Czeizel-féle családi életre nevelés tantárgy tehát épít bizonyos, a családdal kapcsolatban megfogalmazott alapértékekre, amelyek terén már egyáltalán nem feltétlenül van konszenzus a kortárs európai szexuálpedagógiában. (Feltételezésem szerint különösen a háromgyermekes családmodell elsődlegessége kapcsán alakulnának ki éles viták egy szakmai fórumon, de az optimális családtervezés kérdésében sem lenne egyszerü konszenzusra jutni.)

\section{Irodalom}

Allport, G. W. (1997). A személyiség alakulása. Budapest: Kairosz Kiadó.

Asztalos E. \& Nagy L.-né (2012). A szexuális nevelés feladatai és a magyar biológiaoktatás. A Biológia Tanítása, 20(2), 3-20.

Berend M. \& Péterfia É. (1998). Tanári kézikönyv a „Felkészülés a családi életre” tantárgy oktatásához. Budapest: Corvina.

Buda B. (2006). Előszó. In Szilágyi V. (szerk.), Szexuálpedagógia. Szexuális egészségnevelés. Budapest: Athenaeum Kiadó. 9-13.

Castleman, M. (2006). From „Dangers-of-Sex” Education to Joyful Sex Education: How Both Liberals and Conservatives Get It Wrong and How Adult Education Can Help Parents Get It Right. Electronic Journal of Human Sexuality, 9, April 23. www.ejhs.org/volume9/ castleman.htm Utolsó letöltés: 2017. 11. 16.

Egészségjelentés (2015). Nemzeti Egészségfejlesztési Intézet, Budapest. http://www.egeszseg.hu/szakmai oldalak/assets/files/news/egeszsegjelentes-2015. pdf Utolsó letöltés: 2017. 11. 16.

Erikson, E. H. (1997). Az emberi életciklus. In Bernáth L. \& Solymosi,K. (szerk.), Fejlödéslélektani olvasókönyv. Budapest: Tertia Kiadó. 27-41.

Fábián R. \& Simich R. (2006). Meglévő és müködő modellprogramok, valamint az iskolai szexedukációs események értékelése. Budapest: Országos Egészségfejlesztési Intézet.

Forrai J. (1993). Szexuális felvilágosítás és nevelés 10-18 éves korban. Új Pedagógiai Szemle, 43(2), 98-103.

Foucault, M. (1996). A szexualitás története I. A tudás akarása. Budapest: Atlantisz.

Frenkl S. \& Rajnik M. (2007). Életesemények a fejlödéslélektan tükrében. Budapest: Semmelweis Egyetem Mentálhigiéné Intézet - Párbeszéd (Dialógus) Alapítvány.
Grósz E. (2004). Szexuális nevelés. Sepsiszentgyörgy: T3 Kiadó.

Hallstead, J. M. \& Reiss, M. J. (2003). Values in Sex Education: From Principles to Practice. London: Routledge Falmer. DOI: 10.4324/9780203402573

International Technical Guidance on Sexuality Education (2009). Paris: UNESCO. http://unesdoc.unesco.org/images/0018/001832/183281e.pdf Utolsó letö1tés: 2017. 11. 16.

Jung, C. G. (1993). Bevezetés a tudattalan pszichológiájába. Budapest: Európa Könyvkiadó.

Kolonits K. \& Tárkányi Á. (2010). Párkapcsolatra és házasságra nevelés Magyarországon és az USÁ-ban. Mester és Tanitvány, 7(3), 29-45.

Központi Statisztikai Hivatal (2016): Magyarország, 2015. Budapest: KSH. https:/www.ksh.hu/docs/hun xftp/idoszaki/mo/mo2015.pdf Utolsó letöltés: 2017. 11. 16 .

Lehmiller, J. L. (2014). The Psychology of Human Sexuality. Oxford: Wiley-Blackwell.

Lew-Starowicz, Z. (1985). Szexuális partnerkapcsolat. Budapest: Medicina.

Lux E. (2000). Tanfüzet a nemiségröl. In Lux E. (szerk.), Szexológiai olvasókönyv. Budapest: Osiris. Kiadó. 10-15.

McLaren, A. (2002). Szexualitás a 20. században. Budapest: Osiris Kiadó.

Mészáros Gy. (2005). A „rossz arcúak” szava: a kritikai pedagógia kihívása. Iskolakultúra, 15(4), 84-101.

Miksa L. (2005). Családi életre nevelés. Szexuáletika serdülöknek és fiataloknak. Mester és Tanítvány, 2(3), 60-72.

Netsanet, F., Tsion, A., Fessahaye, A., \& Fentie, A. (2012). Parents' perception, students' and teachers' attitude towards school sex education. Ethiopian Journal of Health Sciences, 22(2), 99-107. 
Orji, E. O. \& Esimai, O. A. (2003). Introduction of sex education into Nigerian schools: the parents', teachers' and students' perspectives. Journal of Obstetrics and Gynaecology, 23(2), 185-188. DOI: 10.1080/0744361031000074772

Simich R. et al. (2010). Iskola - egészségfejlesztés szexedukáció. Veszélyeztetett korú diákok prevenciós igényei és szükségletei. Budapest: Országos Egészségfejlesztési Intézet.

Somorjai N. (2016). Figyelni kell rájuk! A szexuális kisebbségekhez tartozó fiatalkorúak nemi nevelése 1-2. Pszichológia \& Practicum, 2(1), 30-31; 2(2), 26-30.

Szilágyi V. (1997). Szexuális szocializáció. Nemi nevelés a családban. Budapest: Medicina.

Szilágyi V. (2006). Szexuálpedagógia. Szexuális egészségnevelés. Budapest: Athenaeum Kiadó.

Tabatabaie, A. (2015). Childhood and adolescent sexuality, Islam, and problematics of sex education: a call for re-examination. Sex Education, 15(3), 276-288. DOI: 10.1080/14681811.2015.1005836
Tárkányi Á. (2011). Családi életre nevelő és házasságra felkészítő iskolai képzések és tanfolyamok külföldön. Új Pedagógiai Szemle, 61(1-5), 135-161.

Tomka,F. (2010): Biztos út. Budapest: Szent István Társulat.

Varga P. (2007): Spielhózni. Budapest: Zászlónk Kiadó.

Weiss, S. P. de, L. C. Atkin, J. N. Gribble, \& P. Andrade-Palos (1991). Sex, Contraception and Pregnancy Among Adolescents in Mexico City. Studies in Family Planning, 22(2), 74-82. DOI: 10.2307/1966778

WHO Európai Regionális Irodája - BZgA (2010): Az európai szexuális nevelés irányelvei. Vázlat a politikusok, nevelési és egészségügyi intézmények és szakemberek részére. www.szexualpszichologia.hu/ who_iranyelvei.html Utolsó letöltés: 2017. 11. 16.

www.americanhumanist.org (az American Humanist Association honlapja), utolsó letöltés: 2017. 11. 16.

Zrinszky L. (2002): Neveléselmélet. Budapest: Müszaki Könyvkiadó.

Absztrakt

Tanulmányunkban megkíséreltük bemutatni az iskolai szexuális nevelés alapvetéseit a magyar és a nemzetközi szakirodalom tükrében. Remélhetőleg sikerült kellőképpen érzékeltetnünk, milyen összetett nevelési területről van szó. A magyarországi iskolák világát ismerő szakemberek számára nem lehet kérdéses, hogy komoly fejlesztésre van szükség Magyarországon e téren. Talán ez a tanulmány is hozzájárulhat ehhez a fejlesztő munkához. 